\title{
Unions in Digital Labour Studies: A Review of Information Society and Marxist Autonomist Approaches
}

\author{
Tai Neilson
}

\author{
Macquarie University, Sydney, Australia, tai.neilson@mq.edu.au
}

\begin{abstract}
A developing research agenda in digital labour studies draws on aspects of information society theory and Marxist autonomism to understand examples of unionisation in digital workplaces and among digital labourers. In this article, I trace core concepts of information society theory and autonomism to demonstrate how unions have been framed by prominent figures in the field. I argue that both approaches tend to relegate unions to industrial capitalism and its historically-specific set of class relations. Information society theorists argue that capitalist class conflict has been transcended, perceiving unions as an obstacle to flexibility and entrepreneurship. Autonomists maintain a focus on class conflict, yet, based on their analysis of contemporary class composition, tend to prioritise other forms of organisation over unions. Digital labour studies research has developed, in part, as a critique of information society theory and draws on aspects of autonomism, including the concepts of precarity and immaterial labour. Authors studying empirical examples of unionisation among digital labourers identify different challenges and opportunities for unionisation among digital labours, and demonstrate the utility of unions for improving the conditions of digital labourers and promoting new working-class subjectivities.
\end{abstract}

Keywords: information society, autonomism, union, digital labour

\section{Introduction}

Digital labour studies is gradually incorporating a more sustained understanding of trade unions and how they may adapt to changing labour markets and workers' demands. This is partly due to the emergence of labour movements and unionisation attempts among workers in call centres, software companies, and digital-first newsrooms. It also corresponds with a 'renaissance' in the study of labour in Communication Studies, Cultural Studies, Media Studies, and related fields. Yet two of the most influential approaches to digital labour - information society theory and Marxist autonomism - have often given unions short shrift and tended to cast them as relics of industrial capitalism. As such, this article sets out to ask: how have unions been framed in information society theory and autonomist approaches to digital labour? And what are some promising examples of research on unions and digital labour?

In large part, scholarship on digital labour has its origins in information society theory and autonomism. They provide a range of terms to describe new types of work, including "knowledge", "information", and "creative" work in addition to "immaterial" and "free" labour (Bell 1974; Florida 2002; Hardt and Negri 2000; Howkins 2001; Machlup 1962; Terranova 2000). Debates about the political economy of the Internet pivot on these concepts (Briziarelli 2014, 621). Like Christian Fuchs $(2014,4)$, I prefer the term "digital labour". Fuchs describes digital labourers as "a collective workforce that is required for the existence, usage and application of digital media". Further, Fuchs and Sevignani (2013) argue that digital labour involves the 
valorisation and exploitation of processes by which people create new products using digital media. It involves creative capacities and digital technologies, and is specific to forms of social organisation that alienate labourers from the means, processes, and products of production $(2013,204)$. Digital labour can be paid or unpaid, and is performed within or outside of employment relations (Huws 2014). Moreover, it exists alongside and in combination with other types of agrarian, industrial, service, and reproductive labour. The term identifies the dialectic relationship of new capacities and technologies with well-established structures of capitalist exploitation. I adopt a more limited definition than Fuchs. Instead of extending the term to encompass those involved in extractive and industrial sectors that are related to the production of digital devices, I focus on the class of workers whose labour is primarily mediated through digital devices, networks, and software. As such, the term emphasises commonalities between workers from academics to call centre employees, whose work is increasingly shaped by similar technologies and processes.

Digital labour studies continues to be framed in significant ways by information society theory and autonomism. Firstly, information society theory may have peaked with Manuel Castells' trilogy The Information Age: Economy, Society and Culture, which was published in the late 1990s. Nonetheless, the influence of this body of work has percolated through various disciplines and venues concerned with technology, development, and economics. This influence is reflected, for instance, in The Information Society Journal and in the tagline for tripleC journal, which, at time of writing, is: "Open Access Journal for a Sustainable Global Information Society". Secondly, autonomist theory and activism has forged the way for critical studies of digital media. Again, triple $C$ journal includes articles by prominent autonomist authors and countless others who are influenced by their work. Information society theory and Marxist autonomism continue to have wide-ranging influence in scholarship, policy, and activism regarding digital labour.

In this article, I focus on information society theory and autonomism because they continue to influence how unions are framed in critical leftist scholarship in this field. At the heart of information society approaches is the description of a new society predicated on information and communication technologies (ICTs) and the growing importance of technical and professional occupations. According to information society theorists, this post-industrial society no longer pivots on capitalist class antagonisms. As such, its proponents relegate working-class institutions such as unions to the dustbin of labour history (Ampuja and Koivisto 2014; Webster 2014, 109). In contrast to information society theory, Marxist autonomism advances a radical critique of capitalism and retains an emphasis on class antagonisms. Despite significant differences between the two approaches, I will argue that Marxist autonomists share a similar aversion to trade unions. Autonomism is distinguished from some other Marxist approaches by its critique of centralised political strategies and organisations including unions, political parties, and statist versions of socialism (Alcoff and Alcoff 2015; Cleaver 2000, 36). Its proponents are sensitive to diverse experiences of oppression and exploitation, decentring Marxism's emphasis on wage labour. This includes an expansive conception of the working class and resistance. However, some prominent autonomist authors are beginning to reappraise the role of unions as enduring forms of working-class organisation (Hardt and Negri 2017).

These are not the only directions from which unions have been analysed or criticised. As well as obvious attacks from the right, the limitations of unions have been expressed by feminist and anti-colonial scholars, other anarchist and Marxist traditions, and union activists themselves (Dalla Costa and James 1972; Taylor 
2014). Further, labour sociologists and industrial relations scholars continue to investigate labour organising and chronicle the many challenges facing unions. For instance, Christian Lévesque and Gregor Murray observe:

Unions have had to contend with much change over the last two decades. Transnational economic restructuring and the relentless pursuit of labor flexibility decenter traditional modes of union action and weaken unions' abilities to defend their members. Long-term movements in the types of jobs people do and in the industries in which they do them, as well as the sociodemographic characteristics of these workers, raise the question of the ability of unions to move into new job territories and to reflect the diversity of people at work. The differing values people bring to work also challenge union identities and prevailing modes of collective action. And public policies have frequently sought to individualize their employment $(2006,1)$.

Researchers in these fields explores the range of union responses to these challenges, although they often do so in isolation from digital labour studies (Engeman 2015; Hurd 1998; Lerner 2012).

Unions continue to face assaults from capital and the state as well as technological and cultural shifts, which make it difficult to organise digital labourers. To this list of challenges, we may add the classification of workers as independent contractors to render them unable to unionise (Scholz 2016), the types of digital piece labour which are performed outside of employment relations for little or no pay (Irani 2015), and free labour performed on online platforms (Fuchs 2013). Unions and workers also face country-specific issues. In China, for instance, official unions are state-controlled and radical workers are forced to operate through unsanctioned organisations and illegal wildcat strikes (Beja 2012; Sandoval 2013). In contrast, "right to work" and other anti-union legislation in the US is eroding union membership and capacities in other ways (Aronowitz 2014). However, Kevin Doogan (2009) argues that left and post-Marxist scholars have conceded too much in their accounts of labour precarity, flexibility, and union decline. He challenges a "pessimistic", "selflimiting" and "self-defeating" meta-narrative, conveyed as much by Daniel Bell and Manuel Castells, as by Michael Hardt and Antonio Negri (Doogan 2009, 30; 80). The scepticism about unions among information society theorists and the criticisms levelled by autonomists reflect the many challenges faced by trade unions.

In digital labour studies, recent empirical studies of labour unions and industrial action are making necessary interventions in this debate by exploring real and virtual opportunities for unionisation in digital workplaces. This work is associated with labour process theory and the political economics of communication, but also draws on concepts from information society theory and autonomism that are specific to digital technologies. In this article, I limit my focus to North America, yet even these examples demonstrate the importance of national specificities and transnational flows. This work focuses on labour movements and unionisation in creative industries (Coles 2016), call centres (Bratich and Brophy 2011), among computer programmers (Rodino-Colocino 2012; Brophy 2006), and in the news and magazine industries (Cohen and de Peuter 2018; Cohen 2016; Salamon 2016). It represents promising directions in digital labour studies. I will trace the core concepts of information society theory and autonomism, outline the ways they frame unions, then return to these examples toward the end of the article. 


\section{The Demise of Class and Unions in Information Society Theory}

Theories of information society constitute one of the most influential approaches to the relationship between digital technologies, society, and work. Their impact extends beyond the academy and has shaped public policy over the past four decades (Garnham 2000, 98). For instance, Bell served on Presidential Committees intended to direct economic and technology policy in the US during the 1960s and 1970s, and Castells' work is cited in European Commission and UNESCO reports and strategies (Jurado-González and Gómez-Barroso 2016, 438). The label 'information society' encompasses a number of terms, including 'post-industrial' and 'network' society, and 'knowledge' and 'creative' economy. They represent different emphases, debates within the body of scholarship, and shifting historical contexts. Yet according to Frank Webster $(2014,9)$ they make a common argument: "quantitative changes in information are bringing into being a qualitatively new sort of social system, the Information Society". Here, I will focus on Bell and Castells' approaches and, in particular, how they frame trade unions. For both authors, the rise of ICTs and the role of information in economics result in the waning of class and working-class institutions.

In his seminal 1974 book The Coming of Post-Industrial Society, Bell advances two interrelated theses: first, he identifies the change from a goods-producing to a service and information economy in the United States; second, he describes the increasing economic and cultural importance of technical and professional occupations (Ampuja and Koivisto 2014). His work should be understood in the context of several sociological and economic narratives about shifts toward the economic primacy of information. For Fritz Machlup (1962), the growing knowledge industry consists of education, research and development, mass media, information technologies, and information services. Similarly, Peter Drucker (1969) describes the shift from an economy based on material goods to a knowledge economy. Bell cites the rising number of workers involved in the production of information, the circulation of "intangible goods", and the provision of services (Bell 1974, 127; 348). Accordingly, technological and scientific changes that make information and knowledge the centre of economic activity result in the transformation of occupational structures and social stratification.

For Bell, the shift to a post-industrial society precipitates the dissolution of working and propertied classes and gives rise to powerful technical and professional social strata. He argues: "if the dominant figures of the past hundred years have been the entrepreneur, the businessman, and the industrial executive, the 'new men' are the scientists, the mathematicians, the economists, and the engineers of the new intellectual technology" (Bell 1974, 344). Whereas capitalism is characterised by property ownership, the pursuit of profits, and the resulting class antagonisms, the new post-industrial society is dependent on education and technical skill. These changes bring about new cleavages and social divisions, but they are not predicated on class antagonism, because members of the emergent technical and professional strata do not exhibit the shared interests, generationally transferred wealth and status, or cultural markers sufficient to be called a class (Bell 1979, 20). In The Cultural Contradictions of Capitalism, he suggests that "as the traditional class structure dissolves, more and more individuals want to be identified, not by their occupational base (in the Marxist sense), but by their cultural tastes and life-styles" (Bell 1976, 15). In short, Bell argues that capitalist class antagonisms no longer structure group interests and identities in post-industrial society, but neither are they replaced by a new class system. 
With a background as a reporter working the labour and industrial relations beat in New York, Bell was familiar with union issues. He also published academic work on unions, including an analysis of the New York longshoremen's union (1960b). In The End of Ideology, Bell (1960a) describes a trade union movement that he sees as "ideologically exhausted and beset with hardening of its organizational arteries" (Bell 1960a, 220). The characteristics of what would later be called information society, as well as internal issues, pushed unions to the edge of a precipice. Bell suggests that "the proletariat is being replaced by the salariat", and he continues that these whitecollar employees "do not speak the old language of labor. Nor can they be appealed to in the old class-conscious terms" $(1960 a, 218)$. He notes that "in the white collar and office field (banks, real estate, insurance, as well as the office forces of large industrial companies), unions have failed signally" (1960a, 215). In line with the thesis of his book, Bell argues that unions had lost their élan (1960a, 218). Unions, in Bell's assessment, would either decline in significance or take on a social movement approach concerned with community and symbolic issues outside of workplace organisation and in coalition with centre-left political parties. Bell's account of the transformation toward information society became the basis for more ardent critiques of unions. The business consultant and author Peter Drucker argues more forcibly that unions are "the most extreme example" of an impediment to innovation and entrepreneurship in information society (1993/1985). He suggests that "the labor union is incapable of even thinking about new challenges, new objectives, new contributions. All it can do is repeat the old slogans and fight the old battles" (Drucker 1993/1985, 181). Arguments about the decline of political institutions and the necessity of flexibility are repeated in Castells' work.

Like Bell, Castells ushers in the information age, although with some terminological and descriptive distinctions. His version of the argument, which is coterminous with the budding popularisation of the Internet and the heyday of globalisation theory, posits the primacy of networks. According to Castells, networks connect people, organisations, and states, but also precipitate fragmentation and restructure social conflicts and identities. Castells is more attentive to the persistence of capitalist economics, the concentration of media ownership, and old and new inequalities. He describes a shift toward informational capitalism associated with the use of ICTs in production and global markets (Castells 1996, 18). Correspondingly, informational labour encompasses occupations that involve the "thinking, conceiving, planning and operationalising required by informational capitalism" (Webster 2014, 125). In a twist on Marxist terminology, Castells outlines the "informational mode of development" (Webster 2014, 110). However, he is convinced that the working class is not an agent of radical political change in this emergent mode of production; rather, he sees a privileged place for identity politics and social movements that cannot be reduced to class (Castells 1997, 64; 359). Further, like Bell, his emphasis on the rise of technical and professional strata rehashes the technocratic argument that "educated elites of one sort or another are the key players in society" (Webster 2014, 115). Castells describes a system of social stratification that is very different from the class antagonisms and cooperation of industrial capitalism: one in which unions play a limited and declining role.

In The Rise of Network Society, Castells (1996) provides a sustained analysis of changes not only to the organisation of workplaces, but also to the relationships between the institutions of workers' power and capital. He describes changes in the organic composition of labour, as factories in the West moved to implement laboursaving technologies and outsource work to countries with cheaper labour costs. As a 
result, the number of workers directly involved in production declined relative to the number of managers and technical professionals (Castells 1996, 265). He suggests that capital has been able to implement almost unilateral reforms since the 1980s, made possible by ICTs and the occasional use of force. This involves pressure to make labour flexible and to shift labour relations toward a model of individual, rather than collective bargaining (1996, 301-302). Under this pressure, labour unions failed to adequately represent a workforce increasingly constituted by women, the young, and migrants, to enter new technology- and information-intensive industries, and to adapt to networked and global enterprises (1996, 301-302). Together, the changes to workplaces and labour-capital relations and the decline of labour unions represent a disaggregation of labour. As a result, the role of class politics and its institutions, including labour unions and parties, is greatly diminished, if not entirely outmoded, in a new, flexible network society. Unions are largely absent from his follow-up, The Power of Identity: The Information Age. Similarly, in his (2011) Communication Power, they are mentioned as just one of many modern social organisations struggling for relevance in a political field structured by networked media.

Bell and Castells trace a similar narrative. Changes that are primarily facilitated by technology have unfolded into a new information age. Among the outcomes is the liquidation of class politics, and its associated labour unions and working-class parties. In their accounts, unions remain only as vestiges of an old mode of development (Ampuja and Koivisto 2014, 459). Further, they suggest that new social movements are most likely to be based on identity and lifestyle, rather than class interests. These accounts of the 'information revolution' constitute a mechanism for appropriating the language of social change that had been associated with more radical voices (Doogan 2009, 30). In response, much of the critical literature in digital labour studies has developed as a critique of information society theory.

\section{Autonomist Theories of Digital Labour and Unions}

Alongside information society theory, autonomist approaches are significant among critical theories of digital labour. I will briefly outline some of their most important theoretical contributions to the field before shifting to a discussion of how autonomists frame labour unions. Chiefly, autonomist contributions to the understanding of digital labour include the social factory, immaterial labour, free labour, and precarity. First, the social factory refers to ways in which productive processes are increasingly performed outside of the factory or fixed workplace (Tronti 1966; Negri 1989, 92). Capitalism relies on activities that occur outside of employment relations and these activities remain subject to intervention from the state and capital (Mueller 2016, 335). Similar to information society theory, autonomists describe the passage from "the domination of industry to that of services and information, a process of post-modernization, or better, informationalization" (Hardt and Negri 2000, 280). The social factory entails an expanded understanding of labour and suggests that relations of production are increasingly embodied in technology. Second, immaterial labour refers to work that increasingly requires "skills involving cybernetics and computer control" and forefront the "information content" of commodities (Lazzarato 1996, 113). It includes "the kinds of activities involved in defining and fixing cultural and artistic standards, fashions, tastes, consumer norms, and, more strategically, public opinion" (Lazzarato 1996, 113). Third, in her canonical article, Tiziana Terranova $(2000,34)$ describes a subset of immaterial labour as free labour: work that is "voluntarily given and unwaged, enjoyed and exploited". Terranova argues that unpaid online contributions are foundational, rather than 
ancillary, to contemporary capitalism. Finally, the neologism "precarity" describes working conditions characterised by flexibility, contingency, and insecurity (Gill and Pratt 2008, 3). They involve a lack of access to paid leave, retirement funds, and health and social benefits, and these conditions are exacerbated by the erosion of social support systems. These concepts constitute what Michael Palm (2011, 433; 435) describes as an "autonomist labor theory" that undermines oppositions between "production and consumption, labor and leisure, or everyday life". According to Greig de Peuter $(2011,418)$, they provide "a counterperspective on the vaunted creative economy". As such, they have important implications for how the interests, identities, and prospects for organisation amongst digital labourers are framed.

In contrast to information society theory, the proponents of Marxist autonomism emphasise the continued importance of class conflict. Yet they are distinguished from some other types of Marxism by their criticisms of centralised forms of working-class organisation, including trade unions and political parties (Thomas 2003). The strident critique of authoritarianism and centralised or hierarchical organisation propounded by autonomists began as a response to Soviet communism, and the compromises of workers' parties and trade unions in Europe during the twentieth century. As Harry Cleaver suggests, autonomists consign "trade unionism, social democracy, workers' councils, and the Leninist party" to a particular historical moment and set of class relations (Cleaver 2000/1979, 67). Their critique of unions also draws from the experiences of anti-colonial and feminist struggles. Rather than provide a comprehensive history or survey of autonomism, my intention is to highlight the ways in which autonomist theorists (especially those available in English) conceptualise unions. ${ }^{1}$ For historical and theoretical reasons, autonomists tend to dismiss labour unions in favour of other types of activism.

Autonomism, which is also labelled workerism or operaismo, emerged in Italy in the 1960s. It responded to the bureaucratisation of the communist party and a union movement that functioned as a corollary of the party and state. Worker and student revolts during May 1968 in France and Italy's 'Hot Autumn' revealed a growing disjuncture between these hierarchical working-class institutions and new, radical struggles. Commenting on the experience of union co-optation in France, Cornelius Castoriadis trenchantly argues that "trade unions, having become cogs in the system, negotiate workers' docility in return for higher wages" (Castoriadis 1988, 227). In Italy, wildcat strikes like those initiated by Fiat factory workers in Turin rejected both the demands of capital and the instructions of their union leaders. These struggles were decisive in cementing autonomist commitments to the self-organisation and self-direction of the working class. In addition to emphasising the agency of the working class, autonomism has come to mean "autonomy from unions and parties, or even autonomy from other sectors of the working class" (Thomas 2003). Cleaver suggests that the communist parties and trade unions revealed their "bankruptcy as an organ of working-class struggle [...and] political strategy" $(2000 / 1979,36)$. He continues, "the central fact that working-class struggles repeatedly surged forward autonomously from, and often against, the influence of either trade unions or the Party was a fundamental subject of discussion, theorization, and debate among that new generation of militants" (Cleaver 2000/1979, 65). In the journal Quaderni Rossi and in Classe Operaia, activists and theorists drew inspiration from the actions of a militant working class.

1 For a more comprehensive survey of Marxist Autonomism see Steve Wright's (2002) Storming Heaven: Class Composition and Struggle in Italian Autonomist Marxism. 
Autonomism provided an alternative for those who were unsatisfied with other forms of Soviet and Western Marxism, and anarchism. It also integrates practical and theoretical insights from anti-colonial and feminist approaches. Among these influences, C.L.R. James' work reveals how black liberation struggles in the US and the Caribbean took place in parallel to, or apart from, unions and parliamentary parties (Taylor 2014). Feminist contributions also emphasise reproductive labour outside of employment relation. Activists and theorists such as Silvia Federici agitate to expand conceptions of the working class to include people involved in domestic and reproductive work. They draw attention to this unpaid and flexible labour disproportionately performed by women (Huws 2014). Feminist interventions include a critique of trade unions: for example, Mariarosa Dalla Costa and Selma James (1972) document ways in which working-class women struggle against the appropriation of their labour in their workplaces and homes coupled with patriarchal union politics. They argue that "for too long political parties, especially of the left, and trade unions have determined and confined the areas of working class struggle" (Dalla Costa and James 1972, 39). Drawing on these influences, autonomism is conceived as an alternative to the bureaucratisation of the workers' movement and entails an expanded conception of the working class.

The analysis of class struggle that was extended to groups outside the workplace required a close study of class composition (Tronti 1966; Ciafaloni, quoted in Hamed 2009). Class composition refers to the shifting ways in which the working class is organised in relation to capital and the changing shape of intra-class divisions. Cleaver argues that autonomists helped identify the role of the unwaged, the peasantry, students, housewives, the unemployed, ethnic and racial minorities, and the Third World in working-class political recomposition $(2000,73)$. In doing so, they demonstrate that class cannot be considered a fixed object of classification; rather, it always undergoes processes of composition, decomposition, and re-composition. These represent moments in the 'cycle of struggles', wherein older forms of workingclass organisation and capacities are decomposed, and new forms are erected in their place. In this process, the working class forces capital to respond and, as a result, drives structural transformations of capitalism.

Unions and working-class political parties are, therefore, associated with a past form of class composition. Hardt and Negri describe "the decline of the effectiveness and role of labor unions, the decline of collective bargaining with labor, and the decline of the representation of labor in the constitution" (2000, 328-329). They review what they see as the weakness of labour unions and parties in the US and suggest that "Working-class power resides not in the representative institutions but in the antagonism and autonomy of the workers themselves" (2000, 269). Similarly, Nick Dyer-Witheford $(2015,38)$ argues that the industrial conditions that established mass worker subjectivities and institutions were destroyed by automation, physical outsourcing, and electronic networks. As a result of these changes "a whole culture of industrial class struggle, including both the technical composition on which it was based and its political composition in political parties, trade unions, community solidarity and militant cadres, was effectively annihilated" (Dyer-Witheford 2015, 38). Autonomists signal a significant shift in class composition facilitated by the rise of ICTs that disperse work further beyond the factory gate to precipitate new types of subjectivity.

A number of authors have attempted to name the new class composition. These monikers include the "tribe of moles" (Bologna 1980), "multitude" (Hardt and Negri 2000), "precariat" (Standing 2011), and "cyber-proletariat" (Dyer-Witheford 2015). 
Most prominently, Hardt and Negri (2000) identify the "multitude": a disparate and global array of subjectivities that now challenge capitalist exploitation and empire. In their account, the decline of institutional workers' organisations means "a new type of resistance has to be invented" (Hardt and Negri 2000, 328). Yet the concept of the multitude has been met with criticism even among authors who agree with much of Negri and Hardt's approach. Franco Berardi $(2011,311)$ contends that the multitude seems "a failed attempt in renaming the subject, after the weakening of the industrial labor force, and the decomposition of the worker class that followed the globalisation and precarization of the 1990s". He continues, "this concept is not sufficient to build the process of subjectivation that we need in the new sphere of global capitalism" (Berardi 2011, 312). Further, Todd Wolfson calls into question the strategies of networked organisation and collective decision-making that Hardt and Negri attribute to the multitude. He argues that "replacing organizational infrastructure with an ungrounded theory of collective decision making that is cultivated through lines of communication seems at best hopeful, and at worst a pathway that plays to capitalist domination" (Wolfson 2011, 376). Autonomists' expanded understandings of work and resistance, in some cases, risk devolving into the celebration of loose networks of activists or defiant activity, which seem unlikely to produce lasting institutions or address the contradictions of capital.

More recently, in their book Assembly (2017), Hardt and Negri respond to critics of their earlier conception of the multitude and the direction of some of their acolytes. In particular, they argue for a renewed emphasis on institutional longevity $(2017,227$ 228). They stipulate that political movements do not need to choose between horizontal organisation and hierarchical leadership and warn against the interpretation of their work as prioritising spontaneous social movements (Hardt and Negri 2017, 6; 21). Yet, for the most part, Assembly continues to depict unions negatively. In Hardt and Negri's appraisal, "traditional trade unions and organizations of the working classes have been utterly broken and corporatized" $(2017,43)$. They warn against indulging in nostalgia for labour unions, which "were designed to contain the workers' movements, liberation movements, and other social struggles" (Hardt and Negri 2017, 161). This accusation is repeated in a recent volume on autonomous workers' struggles edited by Dario Azzellini and Michael Kraft (2018). They suggest "collective bargaining and trade unions attached to the big political parties was a comfortable framework for undermining any demands brought forward by the rank and file for the democratic control of production" $(2018,3)$. As a result, they seek out examples of non-traditional labour organising in their edited volume The Class Strikes Back: Self-Organized Workers' Struggles in the Twenty-First Century.

Together, these examples demonstrate ways in which some prominent autonomist theorists have framed unions as outdated and antithetical to radical class politics. In Hardt and Negri's Assembly, there is, however, a slight revision of their past positions regarding unions.

A change in Hardt and Negri's framing of unions is precipitated by their new search for lasting institutions, admission that vertical forms of organisation can be necessary, and observation that unions have materially supported movements from anti-apartheid to alter-globalisation and Occupy. As a result, they open a small role for unions in the form of "social unionism" and the "social strike". Social unionism has circulated in industrial relations literature and practice since at least the 1960s: in brief, unions need to widen the scope of their actions to encompass the whole lives of their members (education, housing, the environment, etc.) and broaden their 
constituents to include non-full-time workers and communities (Engeman 2015; Lerner 2012). It follows that the social strike brings together "the labor movement's interruption of industrial production and the social movements' disruption of the social order" (Hardt and Negri 2017, 150). Responding to accusations that they have championed spontaneity and horizontalism, Negri and Hardt now seem to, in small part, acknowledge the continuing utility of unions to working-class organisation.

Linda Martín Alcoff and José Alcoff (2015) complain that, in theory, autonomists advance a "generic critique" of organised labour as a form of class collaboration. In practice, "this can come in the form of refusing to partner with specific unions in specific campaigns as well as attempting to disrupt and even destroy unions from within" (Alcoff and Alcoff 2015, 238). This principled rejection abstracts from specific cases of class collaboration to argue that the organisational forms and strategies of labour unions necessarily result in complicity with the state and capital. Alcoff and Alcoff contend that labour movements and unions are far from monolithic in their internal organisation and strategies. "Some", they suggest, "have pretty good ideas about how to fight for significant social change in politically efficacious ways" (2015, 238). What we need, then, is an analysis of how some unions are addressing changing conditions and labour relations between capital and digital labourers.

\section{Examples of Unionisation Among Digital Labourers}

In this final section, I turn to some examples of research about the role of unions among digital labourers. Much of this work is being produced in Canada, where Dallas Smythe (1977) famously called for a focus on labour and Marxist political economy in Communication Studies and, more recently, Vincent Mosco and Catherine McKercher championed the role for unions in the cultural industries with a focus on responses to technological and economic changes (Mosco and Stevens 2010; Mosco and McKercher 2008; McKercher 2002). While there are also researchers working on similar questions in the UK, I will limit my focus to four North American examples: first, Amanda Coles' (2016) investigation of "creative industry" discourses among unions and industry associations in Ontario; second, Enda Brophy's (2009) account of union strategies and industrial action among call centre workers; third, the labour movement among programmers at Microsoft (RodinoColocino 2012; Brophy 2006); and, fourth, examples of unionisation among digital journalists (Cohen and de Peuter 2018; Cohen 2016; Salamon 2016). This work is associated with political economics of communication approaches and labour process theory, but also draws on information society and autonomist theory to different degrees.

Much of the research that continues to draw explicitly on information society theory focuses on the role of ICTs in social and economic policy (Jurado-González and Gómez-Barroso 2016; Olszak, Ziemba and Adamiecki 2009). Technologically determinist versions of information society theory have become commonplace among governments, international donors, businesses, and NGOs (Boeri 2016, 109). And they are generally concerned with increasing employment in creative industries, promoting conditions for knowledge-intensive, flexible, or creative work, and developing an appropriately skilled workforce. Similarly, writing about creative economy discourses, Amanda Coles observes that "[a]s an economic policy framework, the creative economy is framed as a way forward in addressing the challenges of a post-industrial landscape and the fundamentally changing nature of work and employment relations" $(2016,457)$. She contends that creative economy discourses are leveraged to justify "prominent features of labour markets and 
employment relations based on contract, freelance or self-employment, income insecurity, excessive overtime and where risk is both individualized and devolved from the employer to the worker" $(2016,457)$. The creative economy is also depicted as "largely devoid of unions and collective bargaining" (Coles 2016, 461). Yet Coles and others such as David Hesmondhalgh and Sarah Baker (2011) have begun to investigate the role of unions in directing or resisting the changes associated with the information economy.

In her article "Creative Class Politics: Unions and the Creative Economy", Coles investigates creative industry unions in Ontario, which is the site of much of Canada's film and television production. She finds that the unions aligned their campaigns with industry strategy and creative economy discourse. They adopted "arguments used to support international competitiveness based on innovation, and make an economic case for state support of the cultural industries in an era of fiscal restraint" (Coles $2016,457)$. This enabled them to rally workers around shared interests and to gain a voice in public policy, but failed to address concerns about the conditions and quality of work (2016, 468-9). Unions are often neglected in creative economy discourses, which continue to be influenced by information society theory. Coles' work is part of a growing critical literature on information and creative economy policy and cites the need for continued work on unions in the field.

Research on unions which draws on autonomist theory tends to focus on precarious and contract work. Brophy has conducted pioneering work on industrial action at call centres, which he describes as "emergent digital workplaces" (2009, 81), and labour movements among hi-tech workers at Microsoft. In these studies, he rejects the celebratory tone of information society theory and suggests that "knowledge worker theories have been disingenuous in their portraits of engaged call center workers in friction-free informational workplaces" (Bratich and Brophy 2011, 413). Rather, Brophy adopts the concepts of "immaterial labour" and "precarity" from autonomist theory and activism.

Brophy argues for the necessity of unions and highlights the need for experimentation. In the case of the call centre workers employed by Aliant, their strike focused on limiting outsourcing and protected pensions (at least for the short term). Yet the employer continued to actively erode job security and union density as a long-term strategy after the agreement was in place $(2009,94)$. He advocates that as organisations

[attempt] to critique, fashion, invent and refine forms of labour organisation, unions must begin to experiment with strategies to organise geographically, by industry, by occupation, and across intermittent periods of employment if they are to strike back at employers in the process of flexibly restructuring their labour (Brophy 2009, 95).

In the UK, there is also a growing literature on call centre workers. For example, Peter Bain and Phil Taylor (2000; 2008) call attention to worker resistance and union interventions related to employee surveillance and study transnational union activity as a response to the relocation of call centre work to India. These case studies demonstrate ways that unions can experiment and adapt to precarious working conditions in emerging digital workplaces.

Furthermore, Brophy (2006) studies the unionisation of mostly contract (or permatemp) hi-tech workers at Microsoft and other technology companies in the Puget Sound area. He frames the creation of the Washington Alliance of Technology Workers (WashTech) as an experiment in an industry that had been considered 
"immune to collective organizing" (Brophy 2006). WashTech was founded as a Communication Workers of America (CWA) local union, yet the resulting organisation differed from traditional, industrial unions: anyone employed in the sector could join WashTech and it enjoyed relative autonomy from the parent union. WashTech led legislative efforts related to outsourcing and visa programmes, engaged in traditional union drives at companies in the area, facilitated subjective solidarities between some workers, and offered professional training. Brophy also observes obstacles to unionisation, including: precarity and the divisions between contract and full-time employees; a limited tradition of labour organising in the field; and hostility toward unions. In his appraisal, "WashTech is an early, timid, faltering, but very real attempt to route around some of the initial constraints placed on collective organizing by the architects of the knowledge economy" (Brophy 2006). Brophy concludes that the example of mobilisation among digital labourers offers insights into "what is to be done" about "immaterial and precarious labour" (2006).

Studying WashTech from a different perspective, Michelle Rodino-Colocino examines communicative practices through which identities and interests are formulated among digital labourers in her 2012 article "Geek Jeremiads: Speaking the Crisis of Job Loss by Opposing Offshored and H-1B Labor", Rodino-Colocino critically analyses the discourses used to mobilise IT workers around white-collar nationalisms and masculinity that scapegoat immigrant workers. She suggests that they inhibit "solidarity based on class", and are largely ineffective in improving worker conditions or facilitating structural change (Rodino-Colocino 2012, 24). Nonetheless, other voices within the union movement, including WashTech co-founder and thenpresident Marcus Courtney, highlighted class more effectively by drawing a strong contrast between workers and executives (Rodino-Colocino 2012, 37). The analysis highlights tensions among framings of digital labour and the role of unions in an instance of mobilisation. It also demonstrates that the articulation of gender, race, and national identities are integral to digital labour movements.

Finally, in the news industry, technological changes and recent unionisation attempts have spurred studies of industrial relations and digital journalism. In her 2016 book, Writer's Rights: Freelance Journalism in the Digital Age, Cohen focuses on freelance writers and, like Brophy, she uses the concepts of precarity and immaterial labour to describe their labour conditions. She draws a contrast between academic approaches to cultural work based in information society theory, which emphasise empowerment, entrepreneurship, creativity and autonomy, and others which describe a class of workers who are overeducated, underemployed, and face economic uncertainty (Cohen 2016, 9). For Cohen, neither of these approaches fully captures the contradictions of freelance work, which can be simultaneously desirable and precarious. She argues that unionisation efforts are essential to improve the lot of freelancers and should promote collective and working-class subjectivities, which can be particularly difficult among freelance and contract workers. Moreover, organising freelancers entails legal difficulties, because they often occupy a "grey zone" outside of established labour regulations (Cohen 2016, 172). Cohen identifies a number of campaigns and online platforms that bring attention to freelancers' issues. Similarly, Errol Salamon (2016) describes a coalition of freelancers' organisations, which orchestrated an online campaign against exploitative copyright contracts. In North America, these strategies have been employed by professional associations, which, unlike industrial unions, do not have the legal right to engage in collective bargaining or to determine pay rates. In the UK, Edmund Heery et al. $(2004,30)$ describe union strategies in the industry that include publishing rate or fee 
sheets, provision of individual services, and multi-employer bargaining. While freelance writers face legal and cultural barriers to unionisation, some digital journalists have successfully organised their workplaces.

Cohen and de Peuter (2018) study the unionisation of editorial workers at Vice Canada. They find that organisers designed the campaign messaging and bargaining priorities to address workers' concerns about unionisation. Beginning in 2015, the Canadian Media Guild (CMG) drive made VICE the first unionised digital news outlet in Canada. They faced cultural challenges related to technolibertarian and meritocratic ideologies, discourses about flexibility, and the legacy of neoliberal attacks on labour organising. Yet organisers received a positive response among employees and took the campaign beyond the limits of the workplace. They used their technical and communication skills to bring colleagues on board and build public support. Drawing from these exemplary studies of labour movements among digital labourers, we can elaborate a number of common issues for digital labour scholarship and its relationship to both information society theory and Marxist autonomism.

These studies represent a small, but promising, direction in digital labour scholarship, and share some common concerns and approaches. On one hand, their authors tend to be critical of information society approaches. For the most part, they challenge positive discourses about 'flexibility'; although Cohen indicates how workers may pursue flexible or freelance employment and why these realities must be integrated into labour organising strategies, and Coles identifies challenges for workers that are associated with creative economy discourses. On the other, they draw on aspects of autonomist Marxism, but do so selectively. First, they present precarity as a useful concept for describing and mobilising digital labourers. For call centre workers facing outsourcing, contract computer programmers, and freelance writers, precarious working conditions and labour markets constitute a core problem. Second, union drives in these fields are navigating tensions between existing union practices and new workplace cultures. These include professional ideologies and anti-union sentiments. Here, a balance needs to be drawn between bottom-up organising strategies and the strength that can be drawn from existing union structures. Third, digital labourers have communicative skills, which are being leveraged to gain public support. While some of these authors take up concepts from autonomist Marxism in more detail elsewhere (see, for instance, Brophy and de Peuter 2007), for the most part they draw on these concepts selectively. In particular, they use precarity and immaterial labour as descriptive terms, while avoiding other aspects of autonomist theory such as the argument that we inhabit a new type of society, the concept of the social factory, and the critique of centralised forms of organisation. These authors studying empirical examples of unionisation among digital labourers find unions necessary for improving the conditions of digital labourers and promoting new working-class subjectivities.

\section{Conclusion}

Much of the work in digital labour studies emerged as a critique of the celebratory aspects of information society theory. Information society and autonomist theories share some observations about changes in the structure of society and the composition of labour. Both approaches emphasise the increased role of information to the economy, which is facilitated by scientific and technological changes. They also develop overlapping conceptions of 'informational' or 'immaterial' labour, which focus on the supposedly intangible services and commodities that an increasing 
number of workers are involved in producing. However, information society approaches are largely technologically determinist and technocratic (Boeri 2016, 109). With some exceptions in Castells' case, information society is understood as the result of advancements in science and technology, which propel society inevitably forward. These transformations displace the classes associated with industrial capitalism and erode working-class institutions. In contrast, autonomists are what Dyer-Witheford (1994, 86) terms "subversive counter-interpreters" of the information society. Autonomist theory draws from critical and feminist traditions, and in its best renditions emphasises human agency, wherein changes to society result from the struggles between producers and appropriators. Despite different theoretical and political interpretations of the changes associated with information society, proponents of both approaches come to similar conclusions about the fate of labour unions. Prominent theorists in both traditions relegate unions to industrial capitalism and its historically-specific set of class relations.

Information society theorists argue that capitalist class conflict has been transcended, and perceive unions as an obstacle to flexibility and entrepreneurship. They identify some of the historical inadequacy of unions, and Castells, in particular, describes the mechanisms used by capital to disaggregate labour. These changes and deliberate attacks by capital have contributed to declining trends in union membership. Yet, as the basis for public policy, the language and descriptions proffered by information society theory have been wielded by capital and the state as weapons against workers. In this regard, Nicholas Garnham $(2000,98)$ argues that information society presents "itself as both a way of understanding the present historical moment and the dominant development trends in society and at the same time as the favoured legitimating ideology for the dominant economic and political powerholders". Current labour movements in digital workplaces are better understood as the latest iteration of class conflict in which unions continue to play a significant role. Claims made by proponents of information society theory that paint unions and class politics as belonging to a bygone era are untenable in light of the reinvigoration of union campaigns among digital labourers.

Autonomists maintain a focus on class conflict, yet a number of authors relegate unions to the past and implicate unions with class complicity and the bureaucratisation of the labour movement. Their emphases on precarious, unpaid, and reproductive work are indispensable for understanding contemporary capitalism and digital labour. Such an understanding is instructive for union efforts to organise casual, freelance, and even unpaid workers. There are also legitimate criticisms of so-called yellow or business unions that are primarily concerned with retaining duepaying members (Geoghegan 2014; Aronowitz 2014). Nonetheless, many unions have demonstrated their willingness to take risks and invest their resources to engender significant social transformations. Union support during Seattle's alternative globalisation protests and shutdowns orchestrated to support Occupy are examples (Antentas 2015, 473), as are experiments in organising digital workplaces and freelancers that break the mould of industrial labour organising (Brophy 2009; 2006; Cohen 2016). Further, bargaining to change the terms of employment for workers cannot always, or simply, be denounced as class collaboration. These efforts often have direct, positive outcomes for workers and can promote broader social change (Alcoff and Alcoff 2015, 238). As such, the general or principled rejection of unions presents an obstacle to analysing the current role of unions or supporting digital labourers. 
In this article, I have demonstrated the continued importance of information society and autonomist approaches to digital labour studies and presented a systematic account of how these two bodies of research have tended to frame labour unions. It is my intention to spur additional reflection and debate about how they promote some avenues of research about labour movements and have the potential to foreclose others. I have used a reasonably narrow definition of digital labour, but other research in the field is expanding to address additional areas of work, for instance, labour movements among "gig workers" (Woodcock 2017). Future research may continue to investigate labour movements to draw comparisons among industrial unions and professional associations, across types of workplaces, and between past and present experiments in organising digital labourers. Also, while I have focused on North American examples, this field is necessarily transnational. I hope that future research will continue to interrogate the usefulness of concepts drawn from information society theory and Marxist autonomism in terms of how they fit within these traditions and how they might be adapted to meet the needs of specific labour movements. Promising research in this field investigates how labour organisations can improve workers' lives in the present, foster solidarities, and effect more radical change.

\section{References}

Alcoff, Linda Martín and José Alcoff. 2015. Autonomism in Theory and Practice. Science \& Society 79 (2): 221-242. Accessed October 12, 2017. https://guilfordjournals.com/doi/10.1521/siso.2015.79.2.221

Ampuja, Marko and Juha Koivisto. 2014. From 'Post-Industrial' to 'Network Society' and Beyond: The Political Conjunctures and Current Crisis of Information Society Theory. tripleC: Communication, Capitalism \& Critique. Open Access Journal for a Global Sustainable Information Society 12 (2): 447-463. Accessed September 10, 2017. http://www.triple-c.at/index.php/tripleC/article/view/568

Antentas, Josep Maria. 2015. Internationalist Challenges: Antiglobalisation, Occupy, and Indignados. Globalizations 13 (4): 469-483. Accessed October 12, 2017. https://www.tandfonline.com/doi/full/10.1080/14747731.2015.1041270?src=recsys

Aronowitz, Stanley. 2014. The Death and Life of American Labor: Toward a New Workers' Movement. New York: Verso.

Azzellini, Dario and Michael Kraft. 2018. The Class Strikes Back: Self-Organized Workers' Struggles in the Twenty-First Century. Boston: Brill.

Bain, Peter and Phil Taylor. 2008. United by a Common Language? Trade Union Responses in the UK and India to Call Centre Offshoring. Antipode 40 (1): 131-154. Accessed September 20, 2018. https://onlinelibrary.wiley.com/doi/abs/10.1111/j.14678330.2008.00567.x

Bain, Peter and Phil Taylor. 2000. Entrapped by the 'Electronic Panopticon'? Worker Resistance in the Call Centre. New Technology, Work and Employment 15 (1): 2-18. Accessed September 20, 2018. https://onlinelibrary.wiley.com/doi/abs/10.1111/1468$005 X .0006$

Beja, Jean Phillipe. 2012. The New Working Class Renews the Repertoire of Social Conflict. China Perspectives 2: 3-7. Accessed October 12, 2017. https://journals.openedition.org/chinaperspectives/5535

Bell, Daniel. 1979. The New Class: A Muddled Concept. Society. 16 (2): 15-23.

Bell, Daniel. 1976. The Cultural Contradictions of Capitalism. New York: Basic Books.

Bell, Daniel. 1974. The Coming of Post-Industrial Society: A Venture in Social Forecasting. London: Heinemann. 
Bell, Daniel. 1968. The Measurement of Social Change and Technology. In Indicators of Social Change: Concepts and Measurements, edited by Sheldon Moore and Wilbert Ellis, 145-237. New York: Russell Sage Foundation.

Bell, Daniel. 1960a. The End of Ideology: On the Exhaustion of Political Ideas in the Fifties. New York: Free Press.

Bell, Daniel. 1960b. The Racket-Ridden Longshoremen: A Functional Analysis of Crime. In Labor and Trade Unionism, edited by Seymore Galenson and Martin Lipset, 265-282. New York: John Wiley and Sons.

Berardi, Franco. 2011. What About the Dark Side of Multitude? Journal of Communication Inquiry 35 (4): 310-312. Accessed June 5, 2018. http://journals.sagepub.com/doi/pdf/10.1177/0196859911419255

Boeri, Natascia. 2016. Technology and Society as Embedded: An Alternative Framework for Information and Communication Technology and Development. Media, Culture \& Society 38 (1): 107-118. Accessed October 1, 2018. http://journals.sagepub.com/doi/pdf/10.1177/0163443715607845

Bologna, Sergio. 1980. The Tribe of Moles. Semiotext(e) 3 (3): 36-61.

Bratich, Jack and Enda Brophy. 2011. Language Put to Work. Journal of Communication Inquiry 35 (4): 410-416. Accessed June 5, 2018. http://journals.sagepub.com/doi/abs/10.1177/0196859911417437

Briziarelli, Marco. 2014. The Ideological Reproduction: (Free) Labouring and (Social) Working within Digital Landscapes. tripleC: Communication, Capitalism \& Critique. Open Access Journal for a Global Sustainable Information Society 12 (2): 620-631. Accessed September 10, 2017. https://www.triple-c.at/index.php/tripleC/article/view/537

Brophy, Enda. 2009. Resisting Call Centre Work: The Aliant Strike and Convergent Unionism in Canada. Work Organisation, Labour and Globalization 3 (1): 80-99.

Brophy, Enda. 2006. System Error: Labour Precarity and Collective Organizing at Microsoft. Canadian Journal of Communication 31 (3). Accessed June 5, 2018. https://www.cjconline.ca/index.php/journal/article/view/1767/1885

Brophy, Enda and Greig de Peuter. 2007. Immaterial Labor, Precarity, and Recomposition. In Knowledge Workers in the Information Society, edited by Catherine McKercher and Vincent Mosco, 177-191. Lanham, MD: Lexington Books.

Castells, Manuel. 2011. Communication Power. Oxford: Oxford University Press.

Castells, Manuel. 1997. The Power of Identity: The Information Age. Malden: WileyBlackwell.

Castells, Manuel. 1996. The Rise of the Network Society. Malden: Wiley-Blackwell.

Castoriadis, Cornelius. 1988. Modern Capitalism and Revolution. In Political and Social Writings: 1955-1960, from the Workers' Struggle Against Bureaucracy to Revolution in the Age of Modern Capitalism, edited by David Ames Curtis, 226-315. Minneapolis: Minnesota Press.

Cleaver, Harry. 2000/1979. Reading Capital Politically. London: Anti/Thesis.

Cohen, Nicole. 2016. Writers' Rights: Freelance Journalism in a Digital Age. Montreal: McGill-Queens University Press.

Cohen, Nicole and Greig de Peuter. 2018. 'I Work at VICE Canada and I Need a Union': Organizing Digital Media. In Labour Under Attack: Anti-Unionism in Canada, edited by Stephanie Ross and Larry Savage, 114-128. Halifax: Fernwood.

Coles, Amanda. 2016. Creative Class Politics: Unions and the Creative Economy. International Journal of Cultural Policy 22 (3): 456-472. Accessed June 5, 2018. https://www.tandfonline.com/doi/abs/10.1080/10286632.2014.994612?journalCode=gcul2 $\underline{0}$

Dalla Costa, Mariarosa and Selma James. 1972. The Power of Women and the Subversion of the Community. Charlottesville: Falling Wall Press.

De Peuter, Greig. 2011. Creative Economy and Labor Precarity: A Contested Convergence. Journal of Communication Inquiry 35 (4): 417-425. 
Doogan, Kevin. 2009. New Capitalism? The Transformation of Work. Malden: Polity Press. Drucker, Peter. 1993/1985. Innovation and Entrepreneurship. New York: Harper and Row.

Drucker, Peter. 1969. The Age of Discontinuity: Guidelines to Our Changing Society. New York: Harper and Row.

Dyer-Witheford, Nick. 2015. Cyber Proletariat: Global Labour in the Digital Vortex. Chicago: University of Chicago Press.

Dyer-Witheford, Nick. 1994. Autonomist Marxism and the Information Society. Capital \& Class 18 (1): 85-125. Accessed September 10, 2017. http://journals.sagepub.com/doi/pdf/10.1177/030981689405200105

Engeman, Cassandra. 2015. Social Movement Unionism in Practice: Organizational Dimensions of Union Mobilization in the Los Angeles Immigrant Rights Marches. Work, Employment and Society 29 (3): 444-461. Accessed September 5, 2017. http://journals.sagepub.com/doi/abs/10.1177/0950017014552027

Federici, Silvia. 2012/1975. Revolution at Point Zero: Housework, Reproduction and the Feminist Struggle. New York: PM Press.

Florida, Richard. 2002. The Rise of the Creative Class: And how it's Transforming Work, Leisure, Community and Everyday Life. New York: Basic Books.

Fuchs, Christian. 2014. Digital Labour and Karl Marx. New York: Routledge.

Fuchs, Christian and Sebastian Sevignani. 2013. What Is Digital Labour? What Is Digital Work? What's their Difference? And Why Do These Questions Matter for Understanding Social Media? tripleC: Communication, Capitalism \& Critique. Open Access Journal for a Global Sustainable Information Society 11(2), 237-293. Accessed September 10, 2017. https://www.triple-c.at/index.php/tripleC/article/view/461

Fuchs, Christian. 2013. Social Media: A Critical Introduction. London: Sage.

Fuchs, Christian. 2008. Internet and Society: Social Theory in the Information Age. New York: Routledge.

Garnham, Nicholas. 2000. 'Information Society' as Theory or Ideology: A Critical Perspective in Technology, Education and Employment in the Information Age. Information, Communication \& Society 3 (2): 139-152. Accessed 25 June, 2017. https://www.tandfonline.com/doi/abs/10.1080/13691180050123677

Geoghegan, Thomas. 2014. Only One Thing Can Save Us: Why America Needs a New Kind of Labor Movement. New York: The New Press.

Gill, Rosalind and Andy Pratt. 2008. In the Social Factory? Immaterial Labour, Precariousness and Cultural Work. Theory, Culture \& Society 25 (7-8): 1-30. Accessed October 25, 2018. http://journals.sagepub.com/doi/10.1177/0263276408097794

Hamed, Omar. 2009. Lessons from Defeat: Antonio Negri, Autonomist Marxism and Anarcho-Syndicalism from Seventies Italy to Today. Libcom. Accessed 25 June, 2017. https://libcom.org/library/lessons-defeat-antonio-negri-autonomist-marxism-anarchosyndicalism-seventies-italy-toda

Hardt, Michael and Antonio Negri. 2017. Assembly. Oxford: Oxford University Press. Hardt, Michael and Antonio Negri. 2000. Empire. Cambridge: Harvard University Press.

Heery, Edmund, Hazel Conley, Rick Delbridge and Paul Stewart. 2004. Beyond the Enterprise: Trade Union Representation of Freelances in the UK. Human Resource Management Journal 14 (2): 20-35. Accessed June 17, 2018. https://onlinelibrary.wiley.com/doi/pdf/10.1111/j.1748-8583.2004.tb00117.x

Hesmondhalgh, David and Sarah Baker. 2011. Creative Labour: Media Work in Three Cultural Industries. New York: Routledge.

Howkins, John. 2001. The Creative Economy: How People Make Money from Ideas. London: Allen Lane.

Hurd, Richard. 1998. Contesting the Dinosaur Image: The Labor Movement's Search for a Future. Labor Studies Journal 7 (3): 5-30. Accessed January 20, 2017. https://www.tandfonline.com/doi/abs/10.1080/21528586.2002.10419062

Huws, Ursula. 2014. Labor in the Global Digital Economy: The Cybertariat Comes of Age. New York: Monthly Review Press. 
Irani, Lilly. 2015. Difference and Dependence Among Digital Workers: The Case of Amazon Mechanical Turk. South Atlantic Quarterly 114 (1): 225-234. Accessed October 1, 2018. https://read.dukeupress.edu/south-atlantic-quarterly/article/114/1/225-234/3763

Jurado-González, Javier and José Luis Gómez-Barroso. 2016. What Became of the Information Society and Development? Assessing the Information Society's Relevance in the Context of an Economic Crisis. Information Technology for Development 22 (3): 436463. Accessed September 10, 2018.

https://www.tandfonline.com/doi/abs/10.1080/02681102.2016.1155143?journalCode=titd2 $\underline{0}$

Lazzarato, Maurizio. 1996. Immaterial Labor. In Radical Thought in Italy, edited by Michael Hardt and Paolo Virno, 132-146. London: Routledge.

Lerner, Stephen. 2012. A New Insurgency Can Only Arise Outside the Progressive and Labor Establishment. New Labor Forum 20 (3): 9-13. Accessed September 5, 2017. http://journals.sagepub.com/doi/abs/10.4179/NLF.203.0000003

Lévesque, Christian and Gregor Murray. 2006. How Do Unions Renew? Paths to Union Renewal. Labor Studies Journal 31 (3): 1-13. Accessed September 5, 2017. http://journals.sagepub.com/doi/abs/10.1177/0160449X0603100301

Machlup, Fritz. 1962. The Production and Distribution of Knowledge in the United States. Princeton: Princeton University Press.

Maxwell, Richard and Toby Miller. 2012. Greening the Media. New York: Oxford University Press.

McKercher, Catherine. 2002. Newsworkers Unite: Labor, Convergence, and North American Newspapers. Lanham: Rowman \& Littlefield.

Mosco, Vincent and Catherine McKercher. 2008. The Laboring of Communication: Will Communication Workers of the World Unite? Plymouth: Lexington Books.

Mosco, Vincent and Andrew Stevens. 2010. Prospects for Trade Unions and Labour Organisations in India's IT and ITES Industries. Work Organisation, Labour, and Globalisation. 4 (2): 42-62.

Mueller, Gavin. 2016. Piracy as Labour Struggle. tripleC: Communication, Capitalism \& Critique. Open Access Journal for a Global Sustainable Information Society 14 (1): 333345. Accessed September 10, 2017. http://www.triplec.at/index.php/tripleC/article/view/737

Naguib Pellow, David and Lisa Sun-Hee Park. 2002. The Silicon Valley of Dreams: Environmental Justice, Immigrant Workers, and the High-Tech Global Economy. New York: The New York University Press.

Negri, Antonio. 1989. The Politics of Subversion: A Manifesto for the Twenty-first Century. Cambridge: Polity.

Olszak, Celina M., Ewa Ziemba and Karol Adamiecki. 2009. The Information Society Development Strategy on a Regional Level. Issues in Informing Science \& Information Technology 6: 213-224. Accessed September 29, 2018. http://iisit.org/Vol6/IISITv6p2132250lszak618.pdf

Palm, Michael. 2011. Labor's New Empire. Journal of Communication Inquiry 35 (4): 433438. Accessed September 29, 2018. http://journals.sagepub.com/doi/abs/10.1177/0196859911417182

Rodino-Colocino, Michelle. 2012. Geek Jeremiads: Speaking the Crisis of Job Loss by Opposing Offshored and H-1B Labor. Communication and Critical/Cultural Studies 9 (1): 22-46. Accessed October 12, 2017. https://www.tandfonline.com/doi/abs/10.1080/14791420.2011.645490

Salamon, Errol. 2016. E-Lancer Resistance: Precarious Freelance Journalists use Digital Communications to Refuse Rights-Grabbing Contracts. Digital Journalism 4 (8): 9801000. Accessed October 12, 2017. https://www.tandfonline.com/doi/abs/10.1080/21670811.2015.1116953

Sandoval, Marisol. 2013. Foxconned Labour as the Dark Side of the Information Age: Working Conditions at Apple's Contract Manufacturers in China. tripleC: Communication, 
Capitalism \& Critique. Open Access Journal for a Global Sustainable Information Society. 11 (2): 318-347. Accessed September 10, 2017. http://www.triplec.at/index.php/tripleC/article/view/481

Scholz, Trebor. 2016. Uberworked and Underpaid: How Workers Are Disrupting the Digital Economy. Hoboken: Wiley.

Singer, Jane, Alfred Hermida, David Domingo, Ari Heinonen, Steve Paulussen, Thorsten Quandt, Zvi Reich and Maria Vujnovic. 2011. Participatory Journalism: Guarding Open Gates at Online Newspapers. Malden: Wiley-Blackwell.

Smythe, Dallas W. 1977. Communications: Blindspot of Western Marxism. Canadian Journal of Political and Social Theory 1 (3): 1-27.

Standing, Guy. 2011. The Precariat: The New Dangerous Class. London: Bloomsbury.

Taylor, Christopher. 2014. The Refusal of Work: From the Postemancipation Caribbean to Post-Fordist Empire. Small Axe 18 (2): 1-17. Accessed September 10, 2017. https://read.dukeupress.edu/small-axe/article/18/2\%20(44)/1/33319/The-Refusal-of-WorkFrom-the-Postemancipation

Terranova, Tiziana. 2000. Free Labour: Producing Culture for the Digital Economy. Social Text 18 (2): 33-58.

Thomas, Martin. 2003. Autonomist Marxism: Three Themes, Three Critiques. Workers' Liberty. Accessed October 13, 2017. http://www.workersliberty.org/story/2003/12/27/autonomist-marxism-three- themes-threecritiques

Toffler, Alvin. 1980. The Third Wave. New York: Morrow.

Tronti, Mario. 1966. Operai e Capitale [Workers and Capital]. Turin: Einaudi.

Webster, Frank. 2014. Theories of the Information Society. London: Taylor and Francis.

Wolfson, Todd. 2011. Constitutive Communications and the Shimmering Project of the Multitude. Journal of Communication Inquiry 35 (4): 370-377.

Woodcock, Jamie. 2017. Subjectivity in the 'Gig Economy': From the Entreprecariat to Base Union Militancy. Pervasive Labour Union. Accessed July 15, 2018. http://networkcultures.org/entreprecariat/subjectivity-in-the-gig-economy/

Wright, Steve. 2002. Storming Heaven: Class Composition and Struggle in Italian Autonomist Marxism. London: Pluto Press.

\section{About the Author}

\section{Tai Neilson}

Tai Neilson is a lecturer in Media in the Department of Media, Music, Communication and Cultural Studies at Macquarie University in Sydney. He earned his PhD in Cultural Studies from George Mason University in Virginia and MA in Sociology from the New School for Social Research in New York. Dr Neilson has published work on journalism and digital media in Journalism, Fast Capitalism, and Global Media Journal. His current research focuses on the reorganisation of journalists' labour through the use of digital media. 